\title{
Risk assessment for Thai population: benchmark dose of urinary and blood cadmium levels for renal effects by hybrid approach of inhabitants living in polluted and non-polluted areas in Thailand
}

Muneko Nishijo ${ }^{1 *}$, Yasushi Suwazono ${ }^{2}$, Werawan Ruangyuttikarn $^{3}$, Kowit Nambunmee $^{4}$, Witaya Swaddiwudhipong ${ }^{5}$, Kazuhiro Nogawa ${ }^{2}$ and Hideaki Nakagawa ${ }^{1}$

\begin{abstract}
Background: The aim of the present study was to estimate the benchmark doses (BMD) for renal effects for health risk assessment of residents living in Cd-polluted and non-polluted areas in a Thai population.

Methods: The study participants consisted of inhabitants aged 40 years or older who lived in a non-polluted area (40 men and 41 women) and in the environmentally polluted Mae Sot District (230 men and 370 women) located in northwestern Thailand. We measured urinary and blood cadmium (Cd) as markers of long-term exposure and urinary $\beta 2$-microglobulin ( $\beta 2-M G$ ) and $\mathrm{N}$-acetyl- $\beta$-D-glucosaminidase (NAG) as renal tubular effect markers. An updated hybrid approach was applied to estimate the benchmark doses (BMD) and their 95\% lower confidence limits (BMDL) of urinary and blood $\mathrm{Cd}$ for $\mathrm{Cd}$-induced renal effects in these subjects. BMD and BMDL corresponding to an additional risk (BMR) of 5\% were calculated with the background risk at zero exposure set to $5 \%$ after adjusting for age and smoking status.
\end{abstract}

Results: The estimated BMDLs of urinary $C d$ for renal effect markers were 6.9 for urinary $\beta 2-M G$ and 4.4 for NAG in men and 8.1 for $\beta 2-M G$ and 6.1 for NAG $\mu \mathrm{g} / \mathrm{g}$ creatinine (Creat) in women. These BMDLs of urinary $\mathrm{Cd}(\mu \mathrm{g} / \mathrm{g}$ Creat) for NAG were less than the geometric mean urinary $\mathrm{Cd}$ in the polluted area (6.5 in men and 7.1 in women). The estimated BMDLs of blood $\mathrm{Cd}(\mu \mathrm{g} / \mathrm{L})$ were 6.2 for urinary $\beta 2-\mathrm{MG}$ and 5.0 for NAG in men and 5.9 for $\beta 2-\mathrm{MG}$ and 5.8 for NAG in women. The calculated BMDLs were similar or less compared with the geometric mean blood $\mathrm{Cd}(\mu \mathrm{g} / \mathrm{L})$ in the polluted Thai area (6.9 in men and 5.2 in women).

Conclusion: The BMDLs of urinary and blood Cd for renal effects were estimated to be $4.4-8.1 \mu \mathrm{g} / \mathrm{g}$ Creat and $4.4-6.2 \mu \mathrm{g} / \mathrm{L}$ in the Thai population aged $\geq 40$ years old, suggesting that more than $40 \%$ of the residents were at risk of adverse renal effects induced by $\mathrm{Cd}$ exposure in Thailand.

Keywords: Cadmium, Benchmark dose, Urinary cadmium, Blood cadmium, Renal effect

\section{Background}

In the Mae Sot district, Tak Province, northwestern Thailand, serious cadmium (Cd) contamination of soil and rice due to river water contamination suspected from upstream mining activity was reported by the Thai Ministry of Agriculture in 2003. In the polluted area, more than

\footnotetext{
* Correspondence: ni-koei@kanazawa-med.ac.jp

'Department of Public Health, Kanazawa Medical University, 1-1 Daigaku, Uchnada, 920-0293 Ishikawa, Japan

Full list of author information is available at the end of the article
}

$90 \%$ of the rice grain samples were contaminated with $\mathrm{Cd}$ that was greater than $0.2 \mathrm{mg} / \mathrm{kg}(\mathrm{ppm})$, the recommended level by the European Union [1], and $85 \%$ of the surveyed paddy soil samples had a $\mathrm{Cd}$ concentration that was greater than $3 \mathrm{ppm}$, the recommended level by the Codex Committee [2]. A population screening survey for cadmium exposure using urinary cadmium measurement was conducted in 2004 among inhabitants aged 15 years and older living in these cadmium-contaminated villages. Of the 7,697 adults examined, $7.2 \%$ had urinary cadmium

\section{Ciomed Central}

(C) 2014 Nishijo et al.; licensee BioMed Central Ltd. This is an Open Access article distributed under the terms of the Creative Commons Attribution License (http://creativecommons.org/licenses/by/2.0), which permits unrestricted use, distribution, and reproduction in any medium, provided the original work is properly credited. The Creative Commons Public Domain Dedication waiver (http://creativecommons.org/publicdomain/zero/1.0/) applies to the data made available in this article, unless otherwise stated. 
levels $\geq 5 \mu \mathrm{g} / \mathrm{g}$ creatinine (Creat) [2], and the prevalence of renal dysfunction (defined as urinary $\beta_{2}$-microglobulin $(\beta 2-\mathrm{MG}) \geq 1,000 \mu \mathrm{g} / \mathrm{g}$ Creat) was found to be $19.9 \%$ among 527 persons with urinary $\mathrm{Cd}>5 \mu \mathrm{g} / \mathrm{g}$ Creat [3].

The benchmark dose (BMD) method has been adopted to evaluate the health risks of environmental contaminants $[4,5]$. The BMD is defined as the exposure level that corresponds to a specific increase in the probability of an adverse response (benchmark response, BMR), compared with the response at zero background exposure. The lower 95\% confidence limit of the BMD (BMDL) can be used in risk assessment as a replacement for the no observed adverse effect level (NOAEL) [4,5]. For an index of $\mathrm{Cd}$ exposure, urinary $\mathrm{Cd}$ concentration has been adopted because it is mainly influenced by the body burden of cadmium and is proportional to the concentration in the kidney [6]. Consequently, as a health risk assessment of $\mathrm{Cd}$ exposure, several studies in the Japanese population have applied the BMD method to the relationship between renal effect markers and urinary $\mathrm{Cd}$ as an index of internal body burden [7-11]. Recently, estimations of BMD and BMDL for continuous outcomes using the hybrid approach have been developed [12,13]. Using this method, the BMD and BMDL were estimated based on continuous exposure and a continuous effect marker, thereby avoiding categorization of the subjects [13,14]. Accordingly, the statistical validity and efficiency of the BMD and BMDL values were greater using the hybrid approach compared with methods involving categorization of continuous exposure and effect markers. By using this hybrid approach, the BMDL of urinary $\mathrm{Cd}$ for renal effect markers in the Japanese [15-18] and Swedish population have been estimated [19]. However, the relationship between urinary $\mathrm{Cd}$ and renal dysfunction has not been evaluated in the Thai population.

Typically, BMD and BMDL estimations based on the hybrid approach have been conducted in previous studies for urinary $\mathrm{Cd}$, and not for blood $\mathrm{Cd}$. This is because blood $\mathrm{Cd}$ has not been considered the most valid marker of $\mathrm{Cd}$ body burden, but recent exposure [6,20]. However, the high correlation between urinary $\mathrm{Cd}$ and blood $\mathrm{Cd}$ observed in previous studies $[6,21,22]$ indicates that blood $\mathrm{Cd}$ is thought to be a good estimates of cadmium body burden in environmentally exposed populations whose $\mathrm{Cd}$ exposure was consistent. Furthermore, the urinary excretion route of $\mathrm{Cd}$ is the same as with other urinary substances including renal effect markers, and there is some concern about the effects of other substances in urine on the relationship between urinary $\mathrm{Cd}$ and renal dysfunction. Particularly, targeted Thai subjects in the present study showed a high prevalence of urinary tract stones [23], and significant increase in urinary $\beta 2-\mathrm{MG}$ related increased urinary calcium $(\mathrm{Ca}) /$ citrate, a stoneforming risk factor correlated with urinary Cd [24].
Therefore, the aim of the present study was to apply an updated hybrid approach to estimate BMD and BMDL of $\mathrm{Cd}$ exposure for $\mathrm{Cd}$-induced renal effects in a Thai population using both urinary and blood $\mathrm{Cd}$ as exposure markers of $\mathrm{Cd}$.

\section{Methods \\ Study subjects}

The study participants consisted of inhabitants aged 40 years or older who lived in a non-polluted area in the same district (40 men and 41 women) and in the environmentally polluted Mae Sot District (230 men and 370 women) located in northwestern Thailand. The subjects in the polluted area were participants aged $\geq 40$ years in the 2007 health survey (participant rate 83.7\%) targeted for residents whose urinary Cd levels were $\geq 5 \mu \mathrm{g} / \mathrm{g}$ Creat in 2004-5 [25,26]. The numbers of subjects in the nonpolluted area was small, which is a serious limitation of this study, but addition of these subjects in the nonpolluted area increased the low rate of subjects with urinary $\mathrm{Cd}<5 \mu \mathrm{g} / \mathrm{g}$ Creat in the polluted area.

These areas were rural, and their socioeconomic environments were similar. Each participant was interviewed by well-trained nurses about demographic characteristics, smoking status, alcohol consumption, and their medical history of chronic diseases. The subjects were requested to provide urine samples and fasting venous blood samples for biological measurements. The present study protocol was approved by the Ethical Committee of Chiang Mai University in Thailand and Kanazawa Medical University in Japan, and written informed consent was obtained from all subjects prior to participation after explanation of the survey by the medical doctor in Mae Sot General Hospital, one of the authors in the present study.

\section{Sample measurements}

A urine sample from each subject was divided into three aliquots (3-5 $\mathrm{ml}$ each), and all aliquots were frozen and stored at $-20^{\circ} \mathrm{C}$ for later analysis. Prior to storage, one drop of $0.5 \mathrm{~N}$ sodium hydroxide was added to one of the three aliquots of urine showing a $\mathrm{pH}$ of 5 or less to adjust the $\mathrm{pH}$ to $6-8$ to prevent further degradation of $\beta 2-\mathrm{MG}$ in acidic conditions.

Blood and urinary $\mathrm{Cd}$ concentrations were quantified using a flameless atomic absorption spectrometer (Shimadzu Model AAS-6300, Kyoto, Japan). The urine was diluted with $20 \mathrm{mg} / \mathrm{l}$ palladium chloride solution in $5 \% \mathrm{HNO}_{3}$ as a matrix modifier at a ratio of $1: 1$. Proteins in blood were precipitated by $5 \% \mathrm{HNO}_{3}$ at a ratio of $1: 2$ [26]. Method validation of the technique was performed and verified using certified standard reference materials [urine reference material Lot No. 2670 (National Bureau of Standards, Washington D.C., USA) and control blood Lot No. 620302 (Behring Institute, Dresden, Germany)] to 
ascertain the accuracy and precision of the method. Detection limits of urinary and blood Cd were $0.06 \mu \mathrm{g} / \mathrm{g}$ Creat and $0.2 \mu \mathrm{g} / \mathrm{L}$, respectively. The urinary $\mathrm{Cd}$ of each subject was adjusted for urinary Creat concentration, which was measured using an enzyme assay Cica liquid-S (Kantokagaku Reagent Division, Ltd., Japan).

Urinary $\beta 2-\mathrm{MG}$ was measured by enzyme immunoassay using a latex agglutination immunoassay (Eiken Chemical, Japan). Urinary $\mathrm{N}$-acetyl- $\beta$-D-glucosaminidase (NAG) concentration was determined by a colorimetric assay using a NAG test kit (Shionogi Pharmaceuticals, Japan). Concentrations of both urinary NAG and $\beta_{2}-\mathrm{MG}$ were also adjusted per g Creat.

\section{Statistical analysis}

We used the maximum likelihood approach to fit the dose-effect model to the data [12,13]. To obtain a symmetrical distribution, data on $\beta 2-\mathrm{MG}$ and NAG were natural log-transformed. The model for the mean response, $\mu\left(d_{i}\right)$, was assumed to be linear:

$$
\mu\left(d_{i}\right)=\beta_{0}+\beta_{1} \times d_{i}
$$

Where $d_{i}=$ dose for the i-th individual. Urinary Cd or blood $\mathrm{Cd}$, age and smoking status were included in the statistical model and analyzed using multiple linear regression analysis. For urinary and blood Cd levels, Akaike Information Criterions (AICs) of the quadratic, cubic, or logarithmic model were similar or increased compared with that of linear model, and regression coefficients of the quadratic and cubic terms were not significant; therefore, we used the linear model in the present study.

The BMDs and BMDLs were calculated using the hybrid approach, which allows for the calculation of risk of continuous data without dichotomizing the outcome $[13,14]$. The BMR was defined as a $5 \%$ additional risk because a BMDL corresponding to an additional risk of $5 \%$ was close to the NOAEL on average [27]. For positive associations between exposure and renal effects, the effect level associated with a certain BMR equals:

$$
\mu(\mathrm{BMD})=\mu(0)+\sigma\left(\Phi^{-1}[1-P(0)]-\Phi^{-1}[1-P(0)-B M R]\right)
$$

Where $\sigma=$ the standard deviation of residuals, $\Phi^{-1}=$ the inverse of the standard normal cumulative distribution function, and $P(0)=$ the background probability of a response defined in terms of a specified tail proportion of a "hypothetical" control distribution (at urinary/blood $\mathrm{Cd}=0$ ), which in this study was set at $5 \%$. The corresponding continuous cut-off values, $c$, for specified values of renal effect markers in terms of $P(0)$ are given by:

$$
c=\mu(0)+\sigma \times \Phi^{-1}[1-P(0)]
$$

The BMD was calculated by combining the equation for $\mu(\mathrm{BMD})$ with that of the dose-response model [1]:

$$
B M D=\frac{\sigma}{\beta_{1}} \times\left(\Phi^{-1}[1-P(0)]-\Phi^{-1}[1-P(0)-B M R]\right)
$$

The BMDL (defined as the one-sided lower 95\% confidence limit of the BMD) was calculated as representative reference exposure using the profile (maximum) likelihood method, which can be used to compute confidence intervals [12,13].

In addition, we observed that this approach did not require the actual reference population to determine the cut-offs, which may have had a large influence on the estimation of the BMDL [19] because we defined the cut-off for adverse effects as the 95th percentile, which was calculated by the model at no cadmium exposure $(\mathrm{U}-\mathrm{Cd}=0)$. Therefore, any influence of the exposure level on the reference group should have been minimized, and the potential covariates, such as age and smoking status, should have been appropriately adjusted by multiple linear regression analysis.

In the present study, estimation of BMD/BMDL was performed separately in each gender, because our previous studies in a Japanese population showed gender differences in $\mathrm{BMD} / \mathrm{BMDL}$ of urinary $\mathrm{Cd}$ for renal tubular function [7-11].

IBM SPSS 19 J (IBM Business Analytics, Tokyo, Japan) and Microsoft Excel 2010 (Microsoft Corporation, Redmond, WA, USA) were used for the statistical analyses.

\section{Results}

The characteristics of the participants including prevalence of those diseases increasing the risk of renal dysfunction and data on exposure and markers of renal effects grouped according to area, gender and age are shown in Table 1. The number of subjects aged 40-49 in the polluted area was greater than that of the non-polluted area. In the non-polluted area, the geometric means in all aged subjects were $0.5 \mu \mathrm{g} / \mathrm{g}$ Creat in men and $1.1 \mu \mathrm{g} / \mathrm{g}$ Creat in women for urinary $\mathrm{Cd}$ and $0.9 \mu \mathrm{g} / \mathrm{L}$ in men and $0.8 \mu \mathrm{g} / \mathrm{L}$ in women for blood $\mathrm{Cd}$, without a significant difference between age groups. In the polluted area, the geometric means of urinary and blood $\mathrm{Cd}$ for all age groups were significantly greater in both genders compared with those in the non-polluted area: $6.5 \mu \mathrm{g} / \mathrm{g}$ Creat in men and $7.1 \mu \mathrm{g} / \mathrm{g}$ Creat in women for urinary $\mathrm{Cd}$ and $6.9 \mu \mathrm{g} / \mathrm{L}$ in men and $5.2 \mu \mathrm{g} / \mathrm{L}$ in women for blood Cd for total subjects. Urinary $\beta 2-M G$ and NAG were also generally greater in the polluted areas than in the non-polluted areas for both genders and all age groups. Smoking rates were greater in the polluted area compared with the non-polluted area for both genders (Table 1). Although there was no 
Table 1 Characteristics of the participants and data on exposure, renal markers and prevalence of illness grouped according to area and gender

\begin{tabular}{|c|c|c|c|c|c|c|c|c|c|c|c|c|c|c|c|c|}
\hline \multirow{2}{*}{ Age groups (yrs) } & & \multicolumn{5}{|c|}{ Non-polluted area } & \multicolumn{5}{|c|}{ Polluted area } & \multicolumn{5}{|c|}{ Total } \\
\hline & & $40-49$ & $50-59$ & $60-69$ & $\geq 70$ & Total & $40-49$ & $50-59$ & $60-69$ & $\geq 70$ & Total & $40-49$ & $50-59$ & $60-69$ & $\geq 70$ & Total \\
\hline Men & $\mathrm{N}$ & 9 & 9 & 12 & 10 & 40 & 71 & 52 & 54 & 53 & 230 & 80 & 61 & 66 & 64 & 270 \\
\hline Age (yrs) & M (SD) & $44.5(2.8)$ & $54.6(3.1)$ & $64.6(2.9)$ & $76.4(4.9)$ & $61.1(12.4)$ & $44.1(2.7)$ & $52.0(3.2)$ & $63.7(2.7)$ & $75.6(4.4)$ & $55.6(14.0)$ & $44.5(2.7)$ & $54.2(3.2)$ & $63.9(2.8)$ & $75.7(4.5)$ & $56.3(13.9)$ \\
\hline $\begin{array}{l}\text { Urinary Cd } \\
\text { ( } \mu \mathrm{g} / \mathrm{g} \text { Creat) }\end{array}$ & GM (GSD) & $0.4(2.5)$ & $0.5(2.1)$ & $0.7(1.4)$ & $0.5(1.8)$ & $0.5(1.9)$ & $5.9(1.8)$ & $7.0(2.0)$ & $6.9(1.7)$ & $6.3(2.0)$ & $6.3(1.9)$ & $4.4(2.9)$ & $4.8(3.3)$ & $4.5(2.8)$ & $4.1(3.2)$ & $4.5(2.9)$ \\
\hline $\begin{array}{l}\text { Blood cadmium } \\
(\mu \mathrm{g} / \mathrm{L})\end{array}$ & GM (GSD) & $0.9(2.7)$ & $0.7(2.5)$ & $1.0(1.8)$ & $0.9(2.0)$ & $0.9(2.2)$ & $6.1(1.9)$ & $6.7(1.9)$ & $7.8(1.8)$ & $7.3(1.8)$ & $6.9(1.9)$ & $4.9(2.5)$ & $4.9(2.8)$ & $5.4(2.7)$ & $5.1(2.7)$ & $5.1(2.7)$ \\
\hline $\begin{array}{l}\text { B2-MG } \\
\text { ( } \mathrm{gg} / \mathrm{g} \text { Creat) }\end{array}$ & GM (GSD) & $133(2.2)$ & $124(3.4)$ & $214(3.6)$ & $832(3.5)$ & $249.6(4.0)$ & $101(3.6)$ & $500(8.9)$ & $567(8.6)$ & $2221(11.3)$ & $443.3(9.9)$ & $104(3.5)$ & $407(8.4)$ & $475(7.8)$ & $1876(9.8)$ & $407.2(9.0)$ \\
\hline $\begin{array}{l}\text { NAG } \\
\text { (IU/g Creat) }\end{array}$ & GM (GSD) & $3.3(1.6)$ & $5.5(2.2)$ & $4.7(1.7)$ & $8.0(2.5)$ & $5.2(2.1)$ & $4.2(1.7)$ & $5.3(1.9)$ & $6.1(1.7)$ & $7.9(1.7)$ & $5.3(1.9)$ & $4.1(1.7)$ & $5.4(2.0)$ & $5.8(1.7)$ & $7.9(1.8)$ & $5.3(1.9)$ \\
\hline \multicolumn{17}{|l|}{ Smoking habit } \\
\hline Ex-smokers & $\%$ & 44.4 & 55.6 & 45.5 & 36.4 & 45.0 & 25.4 & 28.8 & 35.2 & 54.7 & 31.2 & 27.5 & 32.8 & 36.9 & 51.6 & 33.0 \\
\hline Smokers & $\%$ & 44.4 & 44.4 & 36.4 & 36.4 & 40.0 & 67.6 & 67.3 & 61.1 & 41.5 & 53.1 & 65 & 63.9 & 56.9 & 40.6 & 51.3 \\
\hline \multicolumn{17}{|c|}{ Prevalence of illness } \\
\hline Hypertension & $\%$ & 22.2 & 22.2 & 41.7 & 36.4 & 32.5 & 8.5 & 19.2 & 27.8 & 50.9 & 22.3 & 10 & 19.7 & 30.3 & 48.4 & 23.7 \\
\hline Diabetes & $\%$ & 0.0 & 11.1 & 8.3 & 0.0 & 5.0 & 1.4 & 1.9 & 1.9 & 5.7 & 2.3 & 1.3 & 3.3 & 3.0 & 4.7 & 2.7 \\
\hline Nephrolithiasis & $\%$ & 0.0 & 0.0 & 8.3 & 0.0 & 2.5 & 4.2 & 11.5 & 5.6 & 3.8 & 5.4 & 3.8 & 9.8 & 6.1 & 3.1 & 5.0 \\
\hline Women & N & 10 & 16 & 9 & 6 & 41 & 108 & 119 & 96 & 47 & 370 & 118 & 135 & 105 & 53 & 411 \\
\hline Age (yrs) & M (SD) & $46.3(2.7)$ & $54.9(2.6)$ & $64.2(2.8)$ & $77.2(5.4)$ & $58.1(10.5)$ & $44.6(3.0)$ & $54.2(3.0)$ & $64.1(3.1)$ & $74.8(4.6)$ & $53.1(12.7)$ & $44.7(3.0)$ & $54.3(2.9)$ & $64.1(3.1)$ & $75.1(4.7)$ & $53.5(12.6)$ \\
\hline $\begin{array}{l}\text { Urinary Cd } \\
\text { ( } \mu \mathrm{g} / \mathrm{g} \text { Creat) }\end{array}$ & GM (GSD) & $0.8(2.3)$ & $1.3(2.0)$ & $1.0(3.2)$ & $1.3(1.8)$ & $1.1(2.3)$ & $6.5(2.1)$ & $7.6(1.9)$ & $7.5(2.0)$ & $6.5(1.8)$ & $7.0(1.9)$ & $5.4(2.6)$ & $6.1(2.3)$ & $6.3(2.5)$ & $5.4(2.2)$ & $5.9(2.3)$ \\
\hline $\begin{array}{l}\text { Blood cadmium } \\
(\mu \mathrm{g} / \mathrm{L})\end{array}$ & GM (GSD) & $0.5(1.7)$ & $1.0(2.1)$ & $0.9(2.1)$ & $1.1(1.9)$ & $0.8(2.1)$ & $4.5(2.2)$ & $5.7(1.9)$ & $5.7(2.0)$ & $5.1(1.8)$ & $5.2(2.0)$ & $3.7(2.7)$ & $4.6(2.4)$ & $4.9(2.4)$ & $4.3(2.2)$ & $4.4(2.5)$ \\
\hline $\begin{array}{l}\text { B2-MG } \\
\text { ( } \mu \mathrm{g} / \mathrm{g} \text { Creat) }\end{array}$ & GM (GSD) & $43.9(2.2)$ & $160(4.2)$ & $260(6.4)$ & $1952(8.9)$ & $187.2(6.6)$ & $151.9(6.5)$ & $154(4.7)$ & $311(8.1)$ & $397(7.6)$ & $207.7(6.6)$ & $137(6.3)$ & $155(4.6)$ & $307(7.9)$ & $475(8.0)$ & $205.6(6.6)$ \\
\hline $\begin{array}{l}\text { NAG } \\
\text { (IU/g Creat) }\end{array}$ & GM (GSD) & $2.7(1.7)$ & $5.3(2.3)$ & $4.6(2.1)$ & $10.7(2.0)$ & $4.8(2.3)$ & $4.9(1.7)$ & $5.6(1.7)$ & $6.6(1.8)$ & $8.6(1.8)$ & $5.7(1.9)$ & $4.6(1.8)$ & $5.6(1.8)$ & $6.4(1.9)$ & $8.8(1.8)$ & $5.6(1.9)$ \\
\hline \multicolumn{17}{|l|}{ Smoking habit } \\
\hline Ex-smokers & $\%$ & 0.0 & 6.3 & 44.4 & 83.3 & 24.4 & 11.1 & 27.7 & 53.1 & 42.6 & 26.4 & 10.2 & 25.2 & 52.4 & 47.2 & 26.2 \\
\hline Smokers & $\%$ & 0.0 & 25.0 & 11.1 & 0.0 & 0.1 & 21.3 & 29.6 & 28.1 & 42.6 & 23.2 & 19.5 & 26.7 & 26.7 & 37.7 & 22.2 \\
\hline \multicolumn{17}{|l|}{ Prevalence of illness } \\
\hline Hypertension & $\%$ & 30 & 25 & 22.2 & 50 & 29.3 & 15.7 & 30.3 & 40.6 & 55.3 & 26.8 & 16.9 & 29.6 & 39 & 54.7 & 29.5 \\
\hline Diabetes & $\%$ & 0.0 & 25.0 & 22.2 & 16.7 & 17.1 & 5.6 & 5.9 & 11.5 & 4.3 & 5.9 & 5.1 & 8.1 & 12.4 & 5.7 & 6.9 \\
\hline Nephrolithiasis & $\%$ & 0.0 & 0.0 & 0.0 & 0.0 & 0.0 & 0.0 & 10.9 & 4.2 & 12.8 & 5.2 & 0.0 & 9.6 & 3.8 & 11.3 & 4.8 \\
\hline
\end{tabular}

SD: standard deviation. GM: geometric mean. GSD: geometric standard deviation.

The levels of urinary and blood Cd were significantly greater in the polluted area than those in the non-polluted area for all age groups $(P<0.001$ student's $t$-test). 
difference of prevalence of hypertension between these 2 areas, prevalence of diabetes were generally higher in the non-polluted area compared with those in the polluted area. In contrast, prevalence of nephrolithiasis was greater in the polluted area in both genders (Table 1).

Table 2 shows the results of the multiple linear regression analysis between urinary or blood $\mathrm{Cd}$ and renal markers, grouped according to gender. Both urinary and blood $\mathrm{Cd}$ were related significantly to all of the natural log-transformed renal markers after adjusting for age and smoking habit, indicating the relevance of the dose-effect relationship between $\mathrm{Cd}$ exposure and renal markers. In this study, the significant regression coefficients for 32-MG were 0.06 in men and 0.05 in women for a $1 \mu \mathrm{g} / \mathrm{g}$ Creat increase of urinary $\mathrm{Cd}$ and 0.07 in both genders for a $1 \mu \mathrm{g} / \mathrm{L}$ increase of blood $\mathrm{Cd}$. For urinary NAG, regression coefficients were 0.03 in men and 0.02 in women for $1 \mu \mathrm{g} / \mathrm{g}$ Creat increase of urinary Cd and $1 \mu \mathrm{g} / \mathrm{L}$ increase of blood Cd.

Table 3 shows the BMD and BMDL of urinary and blood $\mathrm{Cd}$ for renal markers in all subjects and in the subjects without nephrolithiasis. The BMDL/BMD values of urinary $\mathrm{Cd}(\mu \mathrm{g} / \mathrm{g}$ Creat) for renal effect markers in all subjects were 6.9/11.3 for $\beta 2$-MG and 4.4/5.8 for NAG in men and 8.1/12.9 for $\beta 2-\mathrm{MG}$ and 6.1/8.4 for NAG in women. These calculated BMDL values for urinary NAG, but not for $\beta 2-\mathrm{MG}$, were less than the geometric mean urinary $\mathrm{Cd}$ in the polluted area, $6.5 \mathrm{in}$ men and $7.1 \mu \mathrm{g} / \mathrm{g}$ Creat in women (Table 1). The BMDL/BMD of blood Cd $(\mu \mathrm{g} / \mathrm{L})$ for renal markers were $6.2 / 10.2$ for $\beta 2-\mathrm{MG}$ and 5.0/7.4 for NAG in men and 5.9/9.1 for $\beta 2-\mathrm{MG}$ and 5.8/8.7 for NAG in women. These calculated BMDLs for both two renal markers in men, but not in women, were less compared with the geometric mean blood $\mathrm{Cd}$ in the polluted area, $6.9 \mathrm{in}$ men and $5.2 \mu \mathrm{g} / \mathrm{L}$ in women (Table 1).

In addition, the BMD and BMDL values of urinary $\mathrm{Cd}$ in women were greater than those in men, but those of blood $\mathrm{Cd}$ in women were less than those in men, suggesting gender differences. Moreover, to eliminate the influence of nephrolithiasis on renal function, the BMD and BMDL of urinary and blood $\mathrm{Cd}$ for renal markers were recalculated in the subjects without nephrolithiasis, but these values were similar to the BMD and BMDL analyzed in all subjects (Table 3 ).

\section{Discussion}

Recently, the reference level of urinary $\mathrm{Cd}$ for renal tubular effects has been reduced to prevent the adverse health effects of low level $\mathrm{Cd}$ exposure in the general

Table 2 Results of the multiple linear regression analysis between urinary $\mathrm{Cd}$ and renal markers grouped according to gender

\begin{tabular}{|c|c|c|c|c|c|}
\hline \multirow[b]{2}{*}{ Renal effect markers ${ }^{a}$} & \multirow[b]{2}{*}{ Explanatory variables } & \multicolumn{2}{|l|}{ Men } & \multicolumn{2}{|l|}{ Women } \\
\hline & & $\mathrm{B}^{\mathrm{b}}\left(95 \% \mathrm{Cl}^{\mathrm{c}}\right)$ & $\mathbf{P}$ & $\mathrm{B}^{\mathrm{b}}\left(95 \% \mathrm{Cl}^{\mathrm{c}}\right)$ & $\mathbf{P}$ \\
\hline \multirow[t]{5}{*}{ B2-MG ( $\mu \mathrm{g} / \mathrm{g}$ Creat) } & Urinary $\mathrm{Cd}(\mu \mathrm{g} / \mathrm{g}$ Creat) & $0.06(0.02-0.10)$ & 0.002 & $0.05(0.02-0.08)$ & 0.001 \\
\hline & Age (yrs) & $0.08(0.06-0.10)$ & $<0.001$ & $0.04(0.02-0.05)$ & $<0.001$ \\
\hline & Smoking habit (/non-smokers) & & & & \\
\hline & Ex-smokers & $0.99(-0.01-1.99)$ & 0.053 & $0.64(0.19-1.09)$ & 0.005 \\
\hline & Smokers & $1.28(0.31-2.26)$ & 0.010 & $0.56(0.11-1.00)$ & 0.015 \\
\hline \multirow[t]{5}{*}{$\beta 2-M G(\mu g / g$ Creat) } & Blood Cd $(\mu \mathrm{g} / \mathrm{L})$ & $0.07(0.02-0.11)$ & 0.003 & $0.07(0.03-0.11)$ & $<0.001$ \\
\hline & Age (yrs) & $0.08(0.06-0.10)$ & $<0.001$ & $0.04(0.02-0.05)$ & $<0.001$ \\
\hline & Smoking habit (/non-smokers) & & & & \\
\hline & Ex-smokers & $0.93(-0.08-1.94)$ & 0.070 & $0.55(0.10-1.00)$ & 0.017 \\
\hline & Smokers & $1.15(0.16-2.14)$ & 0.023 & $0.41(-0.04-0.86)$ & 0.077 \\
\hline \multirow[t]{5}{*}{ NAG (IU/g Creat) } & Urinary Cd ( $\mu \mathrm{g} / \mathrm{g}$ Creat) & $0.03(0.02-0.05)$ & $<0.001$ & $0.02(0.02-0.03)$ & $<0.001$ \\
\hline & Age (yrs) & $0.02(0.01-0.02)$ & $<0.001$ & $0.02(0.01-0.02)$ & $<0.001$ \\
\hline & Smoking habit (/non-smokers) & & & & \\
\hline & Ex-smokers & $0.18(-0.11-0.47)$ & 0.228 & $0.13(-0.01-0.27)$ & 0.078 \\
\hline & Smokers & $0.12(-0.17-0.40)$ & 0.418 & $0.15(0.00-0.29)$ & 0.045 \\
\hline \multirow[t]{5}{*}{ NAG (IU/g Creat) } & Blood Cd $(\mu \mathrm{g} / \mathrm{L})$ & $0.03(0.01-0.04)$ & $<0.001$ & $0.02(0.01-0.04)$ & $<0.001$ \\
\hline & Age (yrs) & $0.02(0.01-0.02)$ & $<0.001$ & $0.02(0.01-0.02)$ & $<0.001$ \\
\hline & Smoking habit (/non-smokers) & & & & \\
\hline & Ex-smokers & $0.17(-0.13-0.47)$ & 0.272 & $0.10(-0.05-0.24)$ & 0.202 \\
\hline & Smokers & $0.08(-0.22-0.37)$ & 0.608 & $0.09(-0.05-0.24)$ & 0.210 \\
\hline
\end{tabular}

${ }^{\mathrm{a} A l l}$ renal markers were natural log-transformed. ${ }^{\mathrm{b}}$ Regression coefficients. ${ }^{\mathrm{c}} 95 \%$ confidence interval. 
Table 3 Benchmark doses of urinary and blood cadmium for renal markers calculated using the hybrid approach in all subjects and subjects without nephrolithiasis

\begin{tabular}{|c|c|c|c|c|}
\hline \multirow[b]{2}{*}{ Renal effect markers ${ }^{a}$} & \multicolumn{2}{|l|}{ Men } & \multicolumn{2}{|l|}{ Women } \\
\hline & Estimated cut-off value $^{b}$ & BMDL (BMD) & Estimated cut-off value ${ }^{b}$ & BMDL (BMD) \\
\hline \multicolumn{5}{|l|}{ Urinary Cd ( $\mu \mathrm{g} / \mathrm{g}$ Creat) } \\
\hline \multicolumn{5}{|l|}{ All subjects } \\
\hline$\beta 2-M G(\mu g / g$ Creat) & 2004 & $6.9(11.3)$ & 1815 & $8.1(12.9)$ \\
\hline NAG (IU/g Creat) & 9.4 & $4.4(5.8)$ & 11.2 & $6.1(8.4)$ \\
\hline \multicolumn{5}{|c|}{ Subjects without nephrolithiasis } \\
\hline$\beta 2-M G(\mu g / g$ Creat) & 1853 & $6.9(11.7)$ & 1767 & $8.2(13.2)$ \\
\hline NAG (IU/g Creat) & 9.2 & $4.2(5.6)$ & 11.1 & $6.0(8.3)$ \\
\hline \multicolumn{5}{|l|}{ Blood Cd $(\mu \mathrm{g} / \mathrm{L})$} \\
\hline \multicolumn{5}{|l|}{ All subjects } \\
\hline$\beta 2-M G(\mu g / g$ Creat) & 1694 & $6.2(10.2)$ & 1664 & $5.9(9.1)$ \\
\hline NAG (IU/g Creat) & 9.8 & $5.0(7.4)$ & 11.6 & $5.8(8.7)$ \\
\hline \multicolumn{5}{|c|}{ Subjects without nephrolithiasis } \\
\hline$\beta 2-M G(\mu g / g$ Creat) & 1947 & $6.4(11.3)$ & 1803 & $5.8(9.0)$ \\
\hline NAG (IU/g Creat) & 10.4 & $5.4(8.4)$ & 12.1 & $5.5(8.3)$ \\
\hline
\end{tabular}

${ }^{\mathrm{a} A l l}$ renal markers were natural log-transformed. ${ }^{\mathrm{b}} \mathrm{Cut}$-off values are adjusted to mean age and non-smoker.

There were 15 cases in men and 23 cases in women of nephrolithiasis.

population. The Joint FAO/WHO Expert Committee on Food Additives (JECFA) determined a provisional tolerable monthly intake (PTMI) of $25 \mu \mathrm{g} / \mathrm{kg}$ body weight [28], which corresponds to the provisional tolerable weekly intake (TWI) of $5.8 \mu \mathrm{g} / \mathrm{kg}$ body weight, reduced from the previous provisional TWI of $7 \mu \mathrm{g} \mathrm{Cd} / \mathrm{kg}$ body weight [29]. Furthermore, the European Food Safety Authority (EFSA) performed a meta-analysis applying the BMD approach to the dose-response relationship between urinary $\mathrm{Cd}$ and $\beta 2-\mathrm{MG}$ in various previous studies [30]. The calculated reference point for urinary Cd was $1 \mu \mathrm{g} / \mathrm{g}$ Creat and it was converted into dietary exposure based on the one-compartment model [31].

In the present study, the calculated BMDLs of urinary $\mathrm{Cd}$ for the renal markers were in the range of $4.4-6.9 \mu \mathrm{g} /$ Creat in men and $6.1-8.1 \mu \mathrm{g} / \mathrm{g}$ Creat in women, which are equal to 33-54 percentile of urinary $\mathrm{Cd}$ in men and 48-55 percentile in women in the polluted area. These results indicate that urinary Cd levels of $46-77 \%$ men and $45-52 \%$ women in the polluted area are more than the BMDLs. Similarly, the calculated BMDLs of blood Cd for the renal markers were in the range of $5.0-6.2 \mu \mathrm{g} / \mathrm{L}$ in men and $5.8-5.9 \mu \mathrm{g} / \mathrm{L}$ in women, suggesting that $42-61 \%$ men and $45-47 \%$ women showed greater blood Cd levels than BMDLs in the polluted area. Because of the high prevalence of nephrolithiasis related to increased urinary $\mathrm{Cd}$ [24] which may influence renal function in the polluted area, BMDLs of urinary or blood $\mathrm{Cd}$ for the renal markers were recalculated in the subjects without nephrolithiasis. However, BMDLs of urinary or blood $\mathrm{Cd}$ for renal markers were quite similar to those values in all subjects, suggesting the high prevalence of nephrolithiasis had no effect on the BMDLs in these populations. We also calculated the BMDLs of urinary $\mathrm{Cd}$ for renal markers with other confounding factors, such as $\mathrm{pH}$ and calcium concentration in urine, but very little difference was observed (data not shown). Therefore, taken together, more than $40 \%$ of the residents aged more than 40 years old in Mae Sot, Thailand were suspected to be at risk of adverse renal effects induced by $\mathrm{Cd}$. Efficient measures to decrease $\mathrm{Cd}$ exposure are necessary for the inhabitants living in these polluted areas in Thailand.

Previously, the BMD method has been applied to estimate the reference point for $\mathrm{Cd}$-related renal dysfunction using urinary $\mathrm{Cd}$, not blood $\mathrm{Cd}$ [7-10,32,33], rice Cd concentration [34], and lifetime $\mathrm{Cd}$ intake [35,36]. However, in most of these studies, estimation of BMD and BMDL was performed using Benchmark Dose Software (BMDS) developed by the United States Environmental Protection Agency (U.S. EPA) [5]. The subjects were categorized according to their exposure level, and the response was dichotomized based on the renal effect marker due to the specification of BMDS. However, according to the hybrid approach, benchmark dose is not dependent upon categorization of exposures, the number of categories, or the dose-intervals, which have marked effects on the results by decreasing statistical power [37]. We then applied the hybrid approach in several recent Japanese studies and observed significant dose-response relationships between urinary $\mathrm{Cd}$ and renal tubular effect markers in the non-polluted subjects with $1.1 \mu \mathrm{g} / \mathrm{g}$ Creat of mean 
urinary $\mathrm{Cd}$ in men and $2.2 \mu \mathrm{g} / \mathrm{g}$ Creat in women $[15,16]$ and in the polluted subjects with $3.2 \mu \mathrm{g} / \mathrm{g}$ Creat of mean urinary $\mathrm{Cd}$ in men and $4.3 \mu \mathrm{g} / \mathrm{g}$ Creat in women [17] in Japan. Smoking rates for men and women in Japan were similar for men and less for women than those of the MaeSot population, Thailand. In these Japanese studies, the estimated BMDLs of urinary $\mathrm{Cd}$ for renal tubular markers ranged from $0.6-4.1 \mu \mathrm{g} / \mathrm{g}$ Creat and $0.6-3.7 \mu \mathrm{g} / \mathrm{g}$ Creat in men and women, respectively after adjusting for age and smoking status [15-17]. In another study conducted in 17,375 adult women living in $16 \mathrm{Cd}$ non-polluted areas in Japan, significant relationships were observed between urinary $\mathrm{Cd}$ and $\beta 2-\mathrm{MG}$ in 15 areas, with the estimated BMDLs of urinary $\mathrm{Cd}$ for $\beta 2-\mathrm{MG}$ ranging from $0.9-3.8 \mu \mathrm{g} / \mathrm{g}$ Creat with a median of $1.4 \mu \mathrm{g} / \mathrm{g}$ Creat [18]. However, in the present study, the calculated BMDLs were greater than those in the Japanese studies. One reason may be that the present subjects in the polluted area were selected residents because of high urinary $\mathrm{Cd}(\geq 5 \mu \mathrm{g} / \mathrm{g}$ Creat) in the 2004-5 survey. Another reason might be a high prevalence of another disease than $\mathrm{Cd}$ nephropathy that increases urinary $\beta 2-\mathrm{MG}$ and NAG in the present area. However, as described in an earlier part of the discussion section, nephrolithiasis which is common in the Thai population, was suspected to be a confounding factor affecting the relationship between urinary $\mathrm{Cd}$ and renal effects, but recalculated BMDLs were not much different after elimination of the nephrolithiasis cases. Moreover, diabetes is well-known to increase urinary $\beta 2-\mathrm{MG}$, but the prevalence of diabetes was less than that in the polluted area than those in the non-polluted area (2.3 for men and 5.9 for women in the Cd-polluted area compared with 5.0 for men and 16.7 for women in the non-polluted area), suggesting no influence of diabetes in the polluted area for increasing renal dysfunction indicated by urinary $32-\mathrm{MG}$. In addition, Caumont et al. [38] reported that the BMDL of urinary Cd was less in ever smokers compared with never smokers in Belgian Cd-exposed workers. Therefore, particularly in Thai residents with a high rate of smoking, elimination of the influence of smoking to estimate BMDL was important, and the hybrid approach was applied to adjust for smoking status and age in the present study.

Although the BMDL of urinary $\mathrm{Cd}$ has been established for renal effects, BMDL estimation based on the hybrid approach has not been conducted for blood Cd in previous studies. One potential reason is the nature of blood $\mathrm{Cd}$. It is well known that urinary $\mathrm{Cd}$ is mainly influenced by the body burden of $\mathrm{Cd}$ and is proportional to the concentration in the kidney $[6,20]$. In contrast, blood $\mathrm{Cd}$ has been considered the most valid marker of recent exposure $[6,20]$. The half-life of blood Cd displays a fast component of 3 to 4 months and a slow component of approximately 10 years [39]. However, the high correlation between urinary and blood $\mathrm{Cd}[6,20,22]$ indicates that urinary $\mathrm{Cd}$ is thought to be a good estimate of cadmium body burden in environmentally exposed populations whose $\mathrm{Cd}$ exposure is consistent. Because such an influential acute $\mathrm{Cd}$ exposure was less likely in the present area because of the prohibition of rice farming at the time the study was performed, we estimated BMDLs of blood $\mathrm{Cd}$ as an index of $\mathrm{Cd}$ exposure in the present study.

Furthermore, blood $\mathrm{Cd}$ was of little relevance to the $\mathrm{Cd}$ concentration in the kidneys. Therefore, a significant relationship between blood $\mathrm{Cd}$ and renal tubular markers found in the present study demonstrated the relationship between $\mathrm{Cd}$ exposure and renal tubular dysfunction. We consider this point is an important notable feature of the present study. Moreover, we defined the cut-off for adverse effects as the 95th percentile, calculated by the model at no cadmium exposure (urinary $\mathrm{Cd}=0$ ) in the study population. Therefore, this approach did not require the actual reference population to determine the cut-offs, which may have a large influence on the estimation of BMDL by the classical method using prevalence [19]. Therefore in the present study, any influence of the exposure level on the reference group was minimized. Additionally, the potential covariates, such as age and smoking status, were adjusted appropriately by multiple linear regression analysis in the present study. Although we believe that further estimation and discussion of the BMDL of blood Cd for renal dysfunction is necessary, we conclude that the reliability of BMDL in the present study was increased considerably, because BMDL that was estimated using blood $\mathrm{Cd}$ as an exposure marker was consistent with that of urinary $\mathrm{Cd}$.

\section{Conclusion}

Estimations of BMDL for renal effects of both urinary $\mathrm{Cd}$ and blood $\mathrm{Cd}$ as exposure markers were useful to increase analytical reliability in a Thai population. The BMDLs of urinary and blood Cd for renal effects were estimated to be $4.4-8.1 \mu \mathrm{g} / \mathrm{g}$ Creat and $5.0-6.2 \mu \mathrm{g} / \mathrm{L}$, respectively, in the Thai population aged $\geq 40$. These BMDLs suggest that more than $40 \%$ of the residents were at a high risk of renal effects induced by $\mathrm{Cd}$ exposure, because these values were in the 33-55 percentiles of urinary and 39-58 percentiles of blood Cd levels in the exposed subjects.

\section{Competing interests}

All authors have approved the final version of the manuscript for publication, and declared all relevant competing interests. There is no competing interest for this paper.

\section{Authors' contributions}

$H N$, and MN participated in the design and coordination of the study. WR, KNo, and WS performed the preparation of survival data and data set creation. SM, YM, KNa, and WS conducted the survey for baseline data collection. YS performed the statistical analysis. MN and YS prepared the draft for the manuscript. All authors read and approved the final manuscript. 


\section{Acknowledgements}

Thanks to all of the participants who live in Mae Sot district, Tak province for their kind cooperation. We thank the staff of Mae Sot General Hospital, especially Ms. Pranee Mahasakpan for their help in the epidemiological survey.

The work was supported by the scientific grant for international collaboration research, Pfizer Health Research Foundation in Japan, the Faculty of Medicine Endowment Fund, Faculty of Medicine, Chiang Mai University, Thailand, and the Grant for Promoted Research from Kanazawa Medical University (S-2012-8), Japan.

\section{Author details}

'Department of Public Health, Kanazawa Medical University, 1-1 Daigaku, Uchnada, 920-0293 Ishikawa, Japan. ${ }^{2}$ Department of Occupational and Environmental Medicine, Graduate School of Medicine, Chiba University, Chiba, Japan. ${ }^{3}$ Division of Toxicology, Faculty of Medicine, Chiang Mai University, Chiang Mai, Thailand. ${ }^{4}$ School of Health Science, Mae Fah Luang University, Chiang Rai, Thailand. ${ }^{5}$ Department of Social Medicine, Mae Sot General Hospital, Mae Sot, Tak Province, Thailand.

Received: 20 January 2014 Accepted: 12 June 2014

Published: 9 July 2014

\section{References}

1. Simmons RW, Pongsakul P, Saiyasitpanich D, Klinphoklap S: Elevated levels of cadmium and zinc in paddy soils and elevated levels of cadmium in rice grain downstream of a zinc mineralized area in Thailand: implications for public health. Environ Geochem Health 2005, 27:501-511.

2. Swaddiwudhipong W, Limpatanachote P, Mahasakpan P, Krintratun S, Padungtod C: Cadmium-exposed population in Mae Sot District, Tak Province: 1: prevalence of high urinary cadmium levels in the adults. J Med Assoc Thai 2007, 90:143-148.

3. Limpatanachote P, Swaddiwudhipong W, Mahasakpan P, Krintratun S: Cadmium-expose population in Mae Sot District, Tak Province: 2: prevalence of renal dysfunction in the adults. J Med Assoc Thai 2009, 92:1345-1353

4. Crump KS: A new method for determining allowable daily intakes. Fundam Appl Toxicol 1984, 4:854-871.

5. U.S. EPA: The Use of the Benchmark Dose (BMD) Approach in Health Risk Assessment. Final report. Washington, DC: Risk Assessment Forum, U.S. Environmental Protection Agency; 1995. Report nr EPA/630/R-94/007.

6. Järup $L$, Åkesson A: Current status of cadmium as an environmental health problem. Toxicol Appl Pharmacol 2009, 2009(238):201-208.

7. Uno T, Kobayashi E, Suwazono Y, Okubo Y, Miura K, Sakata K, Okayama A, Ueshima H, Nakagawa H, Nogawa K: Health effects of cadmium exposure in the general environment in Japan with special reference to the lower limit of the benchmark dose as the threshold level of urinary cadmium. Scand I Work Environ Health 2005, 31:307-315.

8. Kobayashi E, Suwazono Y, Uetani M, Inaba T, Oishi M, Kido T, Nishijo M, Nakagawa $\mathrm{H}$, Nogawa K: Estimation of benchmark dose for renal dysfunction in a cadmium non-polluted area in Japan. J App/ Toxicol 2006, 26(4):351-355.

9. Shimizu A, Kobayashi E, Suwazono Y, Uetani M, Oishi M, Inaba T, Kido T, Nogawa K: Estimation of benchmark doses for urinary cadmium based on beta2-microglobulin excretion in cadmium-polluted regions of the Kakehashi River basin, Japan. Int J Environ Health Res 2006, 16:329-337.

10. Kobayashi E, Suwazono Y, Dochi M, Honda R, Nishijo M, Kido T, Nakagawa H: Estimation of benchmark doses as threshold levels of urinary cadmium, based on excretion of beta2-microglobulin in cadmium-polluted and non-polluted regions in Japan. Toxicol Lett 2008, 179:108-112.

11. Suwazono $Y$, Uetani M, Akesson A, Vahter M: Recent applications of benchmark dose method for estimation of reference cadmium exposure for renal effects in man. Toxicol Lett 2010, 198:40-43.

12. Crump K: Calculation of benchmark doses from continuous data. Risk Anal 1995, 15:79-89.

13. Sand S, Victorin K, Filipsson AF: The current state of knowledge on the use of the benchmark dose concept in risk assessment. J Appl Toxicol 2008, 28:405-421.

14. Crump K: Critical issues in benchmark calculations from continuous data. Crit Rev Toxicol 2002, 32:133-153.
15. Suwazono $Y$, Nogawa $K$, Uetani M, Kido T, Nakagawa H: Reassessment of the threshold of urinary cadmium by using hybrid approach in a cadmium non-polluted area in Japan. Int J Hyg Environ Health 2011, 214:175-178.

16. Suwazono Y, Nogawa K, Uetani M, Miura K, Sakata K, Okayama A, Ueshima H, Stamler J, Nakagawa H: Application of hybrid approach for estimating the benchmark dose of urinary cadmium for adverse renal effects in the general population of Japan. J Appl Toxicol 2011, 31:89-93.

17. Suwazono Y, Nogawa K, Uetani M, Nakada S, Kido T, Nakagawa H: Application of the hybrid approach to the benchmark dose of urinary cadmium as the reference level for renal effects in cadmium polluted and non-polluted areas in Japan. Environ Res 2011, 111:312-314.

18. Sakuragi S, Takahashi K, Hoshuyama T, Moriguchi J, Ohashi F, Fukui Y, Ikeda M: Variation in benchmark dose (BMD) and the $95 \%$ lower confidence limit of benchmark dose (BMDL) among general Japanese populations with no anthropogenic exposure to cadmium. Int Arch Occup Environ Health 2012, 85:941-950.

19. Suwazono Y, Sand S, Vahter M, Filipsson AF, Skerfving S, Lidfeldt J, Akesson A: Benchmark dose for cadmium-induced renal effects in humans. Environ Health Perspect 2006, 114:1072-1076.

20. Järup L, Berglund $M$, Elinder $C G$, Nordberg $G$, Vahter M: Health effects of cadmium exposure - a review of the literature and a risk estimate. Scand J Work Environ Health 1998, 24(Suppl 1):1-51.

21. Åkesson A, Bjellerup P, Lundh T, Lidfeldt J, Nerbrand C, Samsioe G, Skerfving S, Vahter M: Cadmium-induced effects on bone in a population-based study of women. Environ Health Perspect 2006, 114:830-834.

22. Järup L, Hellström L, Alfvén T, Carlsson MD, Grubb A, Persson B, Pettersson C, Spang G, Schütz A, Elinder CG: Low level exposure to cadmium and early kidney damage: the OSCAR study. Occup Environ Med 2000, 57:668-672.

23. Swaddiwudhipong W, Mahasakpan P, Limpatanachote P, Krintratun S: An association between urinary cadmium and urinary stone disease in persons living in cadmium-contaminated villages in northwestern Thailand: a population study. Environ Res 2011, 111:579-583.

24. Suvagandha D, Nishijo M, Swaddiwudhipong W, Honda R, Ohse M, Kuhara T, Nakagawa H, Ruangyuttikarn W: A biomarker found by metabolomics analysis in cadmium exposed residents of Thailand. Int J Envion Res Public Health 2014 11:3661-3677.

25. Honda R, Swaddiwudhipong W, Nishijo M, Mahasakpan P, Teeyakasem W, Ruangyuttikarn W, Satarug S, Padungtod C, Nakagawa H: Cadmium induced renal dysfunction among residents of rice farming area downstream from a zinc-mineralized belt in Thailand. Toxicol Lett 2010, 198:26-32.

26. Ruangyuttikarn W, Panyamoon A, Nambunmee K, Swaddiwudhipong W, Nishijo M: Use of the kidney injury molecule-1 as a biomarker for early detection of renal tubular dysfunction in a population chronically exposed to cadmium in the environment. SpringerPlus 2013, 2:533.

27. Allen BC, Kavlock RJ, Kimmel CA, Faustman EM: Dose-response assessment for developmental toxicity III, statisticcal models. Fundam Appl Toxicol 1994, 23:496-509.

28. FAO/WHO: The Summary report of the 73rd JECFA meeting. Geneva: World Health Organization; 2010.

29. FAO/WHO: Evaluation of certain food additives and contaminants (Thirty-third report of the Joint FAO/WHO Expert Committee on Food Additives). In WHO Technical Report Series, No. 776. Geneva: World Health Organization; 1998.

30. EFSA: Scientific opinion of the panel on contaminants in the food chain on a request from the European commission on cadmium in food. EFSA $J$ 2009, 980:1-139.

31. Amzal B, Julin B, Vahter M, Wolk A, Johanson G, Åkesson A: Population toxicokinetic modeling of cadmium for health risk assessment. Environ Health Perspect 2009, 117:1293-1301.

32. Hong F, Jin T, Zhang A: Risk assessment on renal dysfunction caused by co-exposure to arsenic and cadmium using benchmark dose calculation in a Chinese population. BioMetals 2004, 17:573-580.

33. Jin T, Wu X, Tang Y, Nordberg M, Bernard A, Ye T, Kong Q, Lundstrom N-G, Nordberg GF: Environmental epidemiological study and estimation of benchmark dose for renal dysfunction in a cadmium-polluted area in China. BioMetals 2004, 17:525-530.

34. Kobayashi E, Suwazono Y, Dochi M, Honda R, Kido T: Estimation of benchmark rice cadmium doses as threshold values for abnormal urinary findings with adjustment for consumption of Jinzu River water. Bull Environ Contam Toxicol 2009, 83:102-107. 
35. Kobayashi E, Suwazono Y, Uetani M, Kido T, Nishijo M, Nakagawa H,

Nogawa K: Tolerable level of lifetime cadmium intake estimated as a benchmark dose low, based on excretion of beta2-microglobulin in the cadmium-polluted regions of the Kakehashi River Basin, Japan. Bull Environ Contam Toxicol 2006, 76:8-15.

36. Kobayashi E, Suwazono Y, Dochi M, Honda R, Kido T: Association of lifetime cadmium intake or drinking Jinzu River water with the occurrence of renal tubular dysfunction. Environ Toxicol 2009, 24:421-428

37. Royston P, Sauerbrei W, Altman DG: Modeling the effects of continuous risk factors. J Clin Epidemiol 2000, 53:219-221.

38. Chaumont, De Winter F, Dumont X, Haufroid V, Bernard V: The threshold level of urinary cadmium associated with increased urinary excretion of retinol-binding protein and b2-microglobulin: a re-assessment in a large cohort of nickel-cadmium battery workers. Occup Environ Med 2011, 68:257-264.

39. Järup L, Rogenfelt A, Elinder CG, Nogawa K, Kjellström T: Biological half-time of cadmium in the blood of workers after cessation of exposure. Scand J Work Environ Health 1983, 1983(9):327-331.

doi:10.1186/1471-2458-14-702

Cite this article as: Nishijo et al:: Risk assessment for Thai population:

benchmark dose of urinary and blood cadmium levels for renal effects by

hybrid approach of inhabitants living in polluted and non-polluted areas in

Thailand. BMC Public Health 2014 14:702.

\section{Submit your next manuscript to BioMed Central and take full advantage of:}

- Convenient online submission

- Thorough peer review

- No space constraints or color figure charges

- Immediate publication on acceptance

- Inclusion in PubMed, CAS, Scopus and Google Scholar

- Research which is freely available for redistribution 